\title{
CEO selection in intergovernmental organizations: the clash between control and efficiency in governance
}

\author{
Ryan Federo $^{1}$ (D) Angel Saz-Carranza ${ }^{2}$ Xavier Fernandez-í-Marin ${ }^{3}$. \\ Carlos Losada ${ }^{2}$
}

Accepted: 7 October 2021 / Published online: 23 October 2021

(c) The Author(s) 2021

\begin{abstract}
CEO selection is a crucial governance function influencing and driving the strategic direction of organizations. Extant research has largely assumed that boards are an efficient mechanism vested with the CEO selection function. However, boards are not always delegated with this function. In some organizations, the principals directly select the CEOs to keep effective control over the organization. Drawing on the clashing rationales of control and efficiency, this article identifies the factors influencing the governance choice of whether CEO selection is directly carried out by the principals or channeled through the board. Using a Bayesian logistic regression on a dataset of all global intergovernmental organizations, we find that the substantive character of ownership (i.e., capacity and incentive) matters more than the structure (i.e., diversity and dispersion) in such a governance choice. We also find that organizational characteristics barely have direct and moderating effects on the relationship between ownership structures and the governance choice of CEO selection. Our study has important implications for the literature on CEO selection, and strategic corporate governance research in general.
\end{abstract}

Keywords CEO selection · Board of directors · Control · Efficiency · Intergovernmental organizations $\cdot$ Bayesian statistics

Ryan Federo

ryan.federo@uib.es

1 Universitat de les Illes Balears, Campus Cra. Valldemossa. Km 7, 07122 Palma de Mallorca, Spain

2 ESADE Business School, Universitat Ramon Llull, Ave. Pedralbes, 60-62, 08034 Barcelona, Spain

3 Universitat de Barcelona, Gran Via de les Corts Catalanes, 585, 08007 Barcelona, Spain 


\section{Introduction}

CEO selection is an important aspect of organizational governance (Goel \& Thakor, 2008), since CEOs are crucial to influence and drive the strategic direction of organizations (Hambrick \& Mason, 1984; Miller et al., 1982). Research generally assumes that the board is given the unique responsibility to select and appoint CEOs (Boivie et al., 2016; Hermalin \& Weisbach, 2001; Sebora \& Kesner, 1996). However, the boards are not always vested with the function of selecting CEOs. This phenomenon is often the case in family-owned firms, venture-capital-backed firms, joint ventures, public-private partnerships, meta-organizations, and intergovernmental organizations (IGOs) that typically have identifiable and influential principals who know each other and want to be directly involved in CEO selection (Anderson \& Reeb, 2004; Brunninge \& Nordqvist, 2004; Cannella et al., 2015; Corbetta \& Salvato, 2004; Gulati et al., 2012; Reuer et al., 2011; Smith \& Amoaku-Adu, 1999). Moreover, an increasing number of scholars debate the effectiveness of the board to select the CEOs of firms, since board-picked CEOs are not necessarily associated with superior organizational performance (e.g., Charan, 2016; Chen \& Hambrick, 2012; Khurana, 2001; Mooney et al., 2017). This prior research conveys the relevance of understanding the governance choice of whether CEO selection is performed directly by the principals or delegated to the board.

Extant research on strategic corporate governance offers two potential rationales in CEO-board relations that we argue to be likely triggering this governance choice (c.f., Gulati \& Westphal, 1999; Sundaramurthy \& Lewis, 2003; Westphal, 1999). On the one hand, the principals can protect their own interests by directly monitoring the agent (i.e., control). In this path, the principals more likely will select the CEOs who are expected to pursue their bidding. On the other hand, the principals can delegate the governance function to the board for efficient organizational decision making (i.e., efficiency). This path suggests that CEO selection will likely be delegated to the board in order to facilitate efficient assessments of the candidates to the post. However, we still do not know what influences the governance choice of whether the principals will directly select the CEO or delegate the CEO selection function to the board. This puzzle is what we aim to answer in this study, and thus answer the research question: what influences the governance choice in selecting CEOs?

To do so, we focus on IGOs, defined as organizations that are established by state governments to collectively provide public goods (Federo \& Saz-Carranza, 2018). Similar to other organizational types, IGOs as nonprofit and public sector organizations are prone to agency problems in which the CEO-led secretariats acting as agents might pursue organizational goals that deviate from the mandates and expectations of the member states serving as principals (see Hawkins et al., 2006 and Nielson \& Tierney, 2003 for more detailed discussion regarding the principal-agent relationship between the member states and the secretariats in IGOs). To mitigate the agency problem, the principals have a governance choice to either directly control the agents or use a board to monitor the agents on 
their behalf. CEO selection is a function that embodies such governance choice in IGOs (Federo et al., 2020a, 2020b; Haas, 1990). This governance choice is explicitly addressed in IGOs' founding documents, unlike other types of organizations (e.g., family firms, venture capitalist-backed firms, and joint ventures) that-although formally assigning the CEO selection to the board-may blur the distinction between the owners and the board when it comes to selecting the CEOs. Thus, IGOs fit as the context in analyzing the factors that influence the assignment of the CEO selection function because of the unique spectrum of the explicit governance design discretion in these organizations (e.g., Federo \& SazCarranza, 2020; Johnson \& Urpelainen, 2014).

We draw on the rich literature covering the antecedents of CEO selection (e.g., Berns \& Klarner, 2017; Giambatista et al., 2005; Kesner \& Sebora, 1994) to develop our hypotheses. Using a dataset of all global IGOs, which we refer to those IGOs with members from all continents, we carry out a Bayesian logistic regression to test our hypotheses. We find no evidence suggesting that ownership structure is relevantly related to the governance choice of CEO selection, but the owners' substantive characteristics are related to this choice. We also find that organizational complexity has a direct effect and organizational size has partial moderating effect, while organizational age neither has direct nor moderating effects.

Our study primarily contributes to the literature examining the governance choice and antecedents of CEO selection. We theorize that CEO selection is not only about identifying the characteristics of the suitable candidates and their implications on organizational outcomes, but it also involves who performs the function. Moreover, in this study, we provide evidence of the factors influencing the crucial governance choice of whether the principals would directly control the agent by choosing the CEO or forego effective control to rely on the board for efficient CEO selection.

In the following sections, we first discuss the background literature of CEO selection, highlighting the clashing rationales of control and efficiency. We then develop several hypotheses regarding the different antecedents of CEO selection. Next, we describe our methodology and present our results. We conclude by discussing the implications, recognizing the limitations of our study, and suggesting future research avenues.

\section{Background literature and hypotheses}

Despite the substantial amount of attention received by the topic of CEO in the literature (see reviews on executive succession of Berns \& Klarner, 2017; Giambatista et al., 2005; Kesner \& Sebora, 1994), research on CEO selection is highly fragmented (see review of Busenbark et al., 2016). We still lack a definitive theoretical and empirical understanding of CEO selection, particularly in nonprofit and public sector organizations. Nevertheless, two streams of research have emerged to understand the CEO selection-related phenomena. On the one hand, previous studies report the relationship between CEO selection and firm outcomes such as return on assets and stock prices (e.g., Chung \& Rogers, 1987; Guthrie \& Datta, 1998; Zajac, 1990). On the other hand, prior research analyzes the relationship between several 
antecedents of CEO selection (e.g., Boeker \& Goodstein, 1993). Both these research streams primarily focus on the governance choice of hiring insider or outsider candidates when selecting CEOs.

Our study examines a different governance choice underlying CEO selection. We focus on who decides on CEO selection, which has been commonly viewed in the literature to be under the domain of the board. The tenets of the economic view of agency theory suggest that boards are in a better position to minimize adverse selection (Jensen \& Meckling, 1976), specifically when it comes to hiring CEOs. Zajac (1990) argues that boards are more likely to have the ability to identify and assess the characteristics and qualifications of CEO candidates. Therefore, it is not surprising that extant research generally assumes that boards are vested with the critical responsibility of CEO selection (e.g., Hermalin \& Weisbach, 2001; Sebora \& Kesner, 1996). In fact, CEO selection is an important aspect of the board's monitoring responsibility (Boivie et al., 2016) and it is argued to be the board's ultimate control function (Mizruchi, 1983).

However, boards do not always pick the CEOs. For instance, IGOs demonstrate that the principals may also choose the CEOs, instead of the board. In fact, many IGOs are explicit in their founding documents indicating that the principals are in charge of CEO selection. The World Trade Organization, the International Telecommunications Union, and the International Organization for Migration are among those IGOs whose constitutions unequivocally state that the principals will directly elect the CEOs. This observation deviates from the general assumption that the boards will have the exclusive responsibility of choosing the CEOs to mitigate adverse selection.

Other types of organizations may also have the possibility of the principals choosing the CEOs. For instance, in family-controlled, founder-controlled, and venturecapital-backed firms, the principals and board directors are more likely to be the same people/entities (e.g., Anderson \& Reeb, 2004; Brunninge \& Nordqvist, 2004; Cannella et al., 2011; Corbetta \& Salvato, 2004; Smith \& Amoaku-Adu, 1999). This faultline blurs the distinction whether CEO selection is actually at the discretion of the board or the will of the principals. Similarly, joint ventures suffer the same fate, as ownership is largely concentrated among two or three partners, thus encouraging direct monitoring of the principals to address a potential free rider problem (e.g., Groot \& Merchant, 2000; Reuer et al., 2011). Hence, CEO selection in joint ventures also becomes a resounding issue of whether boards truly select the CEOs or done by parent firms as principals. Other organizations comparable to joint ventures such as meta-organizations (e.g., Gulati et al., 2012), private-public partnerships (e.g., Phan et al., 2005), professional service partnerships (e.g., Greenwood \& Empson, 2003), and trade associations (e.g., Mohr \& Spekman, 1994) may also experience the same governance choice of CEO selection because of the blurring between the principals and the board.

These examples where boards might not be the body in charge of choosing the CEOs raise a theoretical gap on CEO selection. Surprisingly, insights regarding the probability of the principals selecting the CEOs remain overlooked in the literature. We therefore propose that the governance choice in CEO selection is not only about choosing the CEO from a pool of candidates based on specific personal 
characteristics, but also whether CEOs will be selected by the principals or the board. We contend that this alternative view highlights a governance choice underlying CEO selection that embodies the tension between control and efficiency.

\subsection{Control versus efficiency in CEO selection}

The tension between control and efficiency rationales in strategic corporate governance research is based on board-CEO relations (e.g., Gulati \& Westphal, 1999; Sundaramurthy \& Lewis, 2003; Westphal, 1999). Boards are typically torn between maintaining independence to properly control CEO decisions (i.e., control) and providing advice to help CEOs make the appropriate strategic decisions (i.e., efficiency). In the current study, we argue that the governance choice of who selects the CEOs follows the same tension between control and efficiency.

On the one hand, we argue that control in CEO selection pertains to managing the diverging interests among principals during the CEO selection process. This is particularly evident in nonprofit and public organizations with strong and influential principals who are prone to generate principal-principal conflict among shareholders (e.g., Young et al., 2008). A certain level of distrust among the principals pushes for self-preservation by ensuring individual control over key organizational decisions. This behavior can be manifested through CEO selection, in which the principals are more likely incentivized to directly select their preferred agent to orient the organization according to their bidding. Thus, we contend that the principals may attempt to lessen the separation between ownership and control by choosing the CEO whose interests are aligned with theirs, resulting in reduced board governance functions.

On the other hand, we argue that efficiency in CEO selection refers to whether several principals are foregoing multiple agency relationships to ensure efficient decision making (c.f., Allcock \& Filatotchev, 2010; Child \& Rodrigues, 2003). Contrary to control, efficiency rests on collectivist cooperation built on a higher level of trust to become willingly vulnerable (Mayer et al., 1995). Principals may entrust a more efficient body than themselves collectively in order to perform the governance function on their behalf. With this rationale, principals are more likely to delegate the CEO selection function to the board, thereby reflecting the board's known role of mitigating adverse selection.

Building on this tension, we examine what influences the governance choice of CEO selection directly performed by the principals or delegated to the board. We draw on the rich literature on the antecedents of CEO selection-which offers several relevant factors that influence this governance function (e.g., Berns \& Klarner, 2017; Giambatista et al., 2005; Kesner \& Sebora, 1994). More specifically, borrowing the factors that influence the choice of hiring insider or outsider CEO candidates from the CEO selection literature (e.g., Boeker \& Goodstein, 1993; Datta \& Guthrie, 1994; Guthrie \& Datta, 1998; Zajac, 1990), we derive several hypotheses linking different ownership structures and organizational characteristics to the likelihood of the principals selecting the CEOs or delegating the CEO selection function to the board. Since governance design substantially varies across different types of organizations (Aguilera et al., 2008), we also investigate how different organizational 
characteristics moderate the relationship between ownership structures and the governance choice.

\subsection{The role of ownership structure on CEO selection}

One of the drivers of organizational self-identification to increase motivation and incentivize increased involvement in oversight and strategic decision making is ownership (e.g., Filatotchev \& Bishop, 2002; Hammer \& Stern, 1980). Ownership structure is a strong determinant of governance design variation among different organizations (La Porta et al., 1999). Extant research shows that ownership diversity and concentration are two aspects of ownership structure influencing executive successions (e.g., Handler, 1994; Kang \& Shivdasani, 1995). Following previous studies, we analyze how ownership structure influences CEO selection. Given the nonprofit and public nature of our context, we refer to ownership structure as an overall umbrella of organizational shareholding structure which may refer to the members of nonprofit associations, governmental ownership for public organizations, or assembly of member states in the case of the context of this study: IGOs.

\subsubsection{Ownership diversity}

The agency approach assumes that principals generally have homogenous preferences. However, principals often cluster into separate strategic groups with heterogenous preferences that are more likely to be conflicting (Federo et al., 2020a, 2020b; Hoskisson et al., 2002; Peng et al., 2004), which may result in principalprincipal conflict (Young et al., 2008). Ownership diversity occurs when principals substantially differ in terms of their characteristics and intentions (Sur et al., 2013), whether such owners are the state, foreign or local entities, individuals, family, business group, or funds, among others (Denis \& McConnell, 2003). It can also affect the kind of CEO selected, since a dominant characteristic among the owners would suggest converging interests (Boeker \& Goodstein, 1993).

In addition, ownership diversity reduces characteristic-based trust (Zucker, 1986), incentivizing the principals to protect their own preferences by directly controlling various organizational decision making, including CEO selection that influences organizational strategies. In organizations with diverse ownership, uncertainty arising from fellow principal preferences may encourage active principal participation during CEO selection. Furthermore, because of the possibility that principals vary in their control over the organization (e.g., property rights and status), those principals with greater control than others may engage in opportunistic behavior (i.e., choosing their representative as the CEO) that only benefits them. This may also drive down trust among the principals and can push for direct participation to select the CEOs. Therefore, we expect that diverse ownership increases the likelihood that CEO selection will be carried out by the principals to reduce the separation of ownership and control and that less diverse ownership increases the likelihood that CEO selection is delegated to the board. 
Hypothesis 1 The less diverse is the ownership, the higher is the likelihood of CEO selection delegated to the board.

\subsubsection{Ownership dispersion}

How ownership is distributed determines overall governance designs (Bebchuk \& Roe, 1999). Concentrated ownership suggests high principal control (Demsetz \& Lehn, 1985) because of increased incentive to monitor and bring about changes into the organization (Bethel \& Liebeskind, 1993). Whereas, dispersed ownership implies reduced principal control and greater managerial power (Greckhamer, 2016) because small shareholding places principals in a position of having minimal incentive and capacity to exert influence over management (Coffee, 2001; Leech \& Leahy, 1991). We argue that these assumptions radiate as well to CEO selection. On the one hand, in organizations with concentrated ownership, there are high risks associated with large investments which incentivize the principals to choose their preferred CEO to protect their interests (Leech \& Leahy, 1991). On the other hand, organizations with dispersed ownership have many principals and are likely to be professionally managed (Finkelstein \& Hambrick, 1989), making the principals lose grasp over key organizational decision making.

Group size is the classic driver of collective action problems (Olson, 1965). Although there is increased need for control due to the aggravated agency problem of management self-interests dominating principal interests (Daily et al., 2003), high ownership dispersion bears risk of free riding among the principals to monitor the agents (Gorton \& Schmid, 1999). With many principals who have low incentive to monitor, delegating the governance function-which includes CEO selection-to the board becomes a more efficient decision-making mechanism than doing it themselves. In this case, boards are more likely to select the CEOs than the owners because they can efficiently balance out diverging interests of multiple principals, while effectively ensuring to choose the suitable candidate to the post.

Hypothesis 2 The more dispersed is the ownership, the higher is the likelihood of CEO selection delegated to the board.

\subsection{The effect of organizational characteristics}

Governance varies across different organizations (Aguilera et al., 2008). Several organizational characteristics such as complexity, size, and age are typical contextual conditions influencing CEO selection (e.g., Datta \& Guthrie, 1994; Guthrie \& Datta, 1998; Zhang \& Rajagopalan, 2003). We borrow these organizational characteristics that were used in previous studies to analyze how such factors influence the choice of the principals directly selecting the CEO or delegating the CEO selection to the board. 


\subsubsection{Organizational complexity}

Organizational complexity refers to the amount of differentiation along various elements and processes constituting the organization (Dooley, 2002). It covers a wide range of organizational design structures and features such as having multiple sub-units, governance levels, and highly developed processes (Brickley et al., 1997), which impose greater information-processing tasks on the governance body (e.g., Bushman et al., 2004; Henderson \& Fredrickson, 1996). Because of information asymmetry arising from the disconnect of principals from the operations, they typically have imperfect knowledge to make important decisions like selecting the suitable CEO to manage the complex organizational settings. The boards then become the efficient mechanism to perform governance functions on behalf of the principals. Boards are closer to the operations than the owners, thus making them in a better position to understand organizational processes and identify the leadership requirements for the organization. Hence, we expect that complex organizations are more likely to have the board delegated with the CEO selection function.

Hypothesis 3 In more complex organizations, the principals are more likely to delegate the CEO selection function to the board instead of selecting the CEO themselves.

\subsubsection{Organizational size}

Research typically assumes size as an important contingency variable in CEO selection (Guthrie \& Datta, 1998). Size is an indicator of tangible resources, suggesting large pools of financial and managerial resources that can help prevent organizational failure (Mitchell, 1994). Large organizations attract not only capital but also qualified labor (Bruderl \& Shussler, 1990). Like complexity, size determines how highly developed are the organizational structures and processes. Large organizations in general are more difficult to manage and coordinate internal activities than small ones (Chandler, 1962). When it comes to CEO selection, the combination of available labor and challenges to understand organizational operations exacerbates the risk of adverse selection if carried out by the principals who lack knowledge about how the organization operates. This prevents the principals to become better evaluators than the board in determining the fit between CEO candidates' qualifications and organizational needs. In this regard, the board becomes the efficient structure to select the CEOs because of its closer proximity than the owners to the organization's day-to-day activities (Zahra \& Pearce, 1989).

Hypothesis 4 In larger organizations, the principals are more likely to delegate the CEO selection function to the board instead of selecting the CEO themselves.

\subsubsection{Organizational age}

Older organizations are already more formalized when it comes to its functioning than younger ones (Pugh et al., 1968). Such organizations more likely have developed widely accepted and institutionalized specific routines and cultures that are embedded into organizational systems (Cyert \& March, 1963). In fact, Guthrie and Datta (1997) 
found that organizational age is correlated with the likelihood of candidates with longer tenure and substantial experience within the organization to be elected as CEOs because of their existing knowledge about the organization. Age increases processbased trust within organizations (Kale et al., 2002). As time goes by, it is likely that organizational actors will build mutual experience, forging trust in the process (Stuart \& Podolny, 1996; Zucker, 1986). The more trust emerges with time, direct control of principals over the agent becomes less relevant (Gulati \& Westphal, 1999). We construe that CEO selection is among those organizational functions that also have developed over time. Old organizations are likely to have an established process in which the principals would already be more willing to delegate such function to the board.

Hypothesis 5 In older organizations, the principals are more likely to delegate the CEO selection function to the board instead of selecting the CEO themselves.

\subsubsection{The moderating effects of organizational characteristics}

Corollary to the aforementioned hypotheses, Durand and Vargas (2003) argue that organizational complexity can moderate the effect of ownership structure on organizational performance. Although they have not found any support for this thesis, and neither have Greenwood et al. (2007) found support to both the direct and indirect effects of organizational complexity on organizational performance, we argue that these relationships may also be important when it comes to CEO selection and are worthy of further testing. Organizational complexity exacerbates information asymmetry, heightens managerial opportunism, and increases monitoring costs, particularly on organizations with diverse and dispersed ownership structures. This can be attributed to the increased uncertainty requiring greater complex governance mechanisms than direct owner control (Durand \& Vargas, 2003).

Moreover, although organizational complexity and size are typically correlated because they both indicate organizational breadth and development (Bushman et al., 2004), it is important to account them separately because a large organization does not necessarily mean that the organization would also be complex, and vice versa (Hall et al., 1967). Both organizational complexity and size may influence the governance choice of CEO selection because complex and large organizations may require close proximity to the day-to-day operations, which disperse and diverse owners typically lack knowledge in determining the leadership needs of the organization (Federo et al., 2020a, 2020b). Thus, it is logical for CEO selection to be delegated to the board that has closer proximity to the organization and more likely to have better understanding of the organizational governance needs than the owners.

In addition, organizational age is also an indicator of the level of bureaucratization that can help facilitate or restrict certain organizational processes (Pierce \& Delbecq, 1977). Older organizations tend to be highly bureaucratic and have greater structural inertia to respond to environmental changes than newer ones (Hannan \& Freeman, 1984). Thus, in organizations with diverse and/or disperse owners who are less likely to build a common culture and share goal such as selecting the CEO than homogeneous and/or concentrated owners (c.f., Le Mens et al., 2015), we argue that the CEO selection is likely to be delegated to the board. 
In sum, the effect of ownership structure on the choice whether CEO selection would be carried out by the principal themselves or delegated to the board is likely to be influenced by these organizational characteristics. Because of increased bureaucratization, more complex, larger, or older organizations are more likely to intensify the relationship between ownership structures and CEO selection delegated to the board.

Hypothesis 6a Organizational complexity intensifies the relationship of ownership diversity and dispersion with the likelihood of CEO selection delegated to the board.

Hypothesis $6 \mathrm{~b}$ Organizational size intensifies the relationship of ownership diversity and dispersion with the likelihood CEO selection delegated to the board.

Hypothesis 6c Organizational age intensifies the relationship of ownership diversity and dispersion with the likelihood of CEO selection delegated to the board.

\section{Methodology}

\subsection{Sample and data}

We hand collected data on all global IGOs, which totals to 69, during the first quarter of 2016. We focused on global IGOs to account for principal diversity that typically lacks in regional IGOs with similar principals. We built a database

Table 1 Description of the data

\begin{tabular}{lll}
\hline Variable & $\begin{array}{l}\text { CEO selection is performed } \\
\text { by the principals themselves } \\
(\mathrm{n}=35)\end{array}$ & $\begin{array}{l}\text { CEO selection is } \\
\text { delegated to the board } \\
(\mathrm{n}=34)\end{array}$ \\
\hline Ownership diversity: heterogeneity & $\begin{array}{l}0.28 \\
(0.25,0.31)\end{array}$ & $\begin{array}{l}0.31 \\
(0.29,0.31)\end{array}$ \\
Ownership dispersion: number of members & 77 & 168 \\
& $(54,148)$ & $(76,187)$ \\
Organizational complexity: BI complex & 7 & 14 \\
Organizational size: Budget (log) & $(20.0 \%)$ & $(41.2 \%)$ \\
Organizational age & 14 & 67 \\
Rotational board membership & $(4,92)$ & $(9,345)$ \\
Financial institution & 49 & 58 \\
& $(28.64)$ & $(38,82)$ \\
Unequal peers & 3 & 5 \\
& $(8.6 \%)$ & $(15 \%)$ \\
& 3 & 7 \\
\hline
\end{tabular}

Continuous variables are reported with their means and in parenthesis are the confidence interval; Binary variables are reported with the number of observations and in parenthesis are the corresponding percentage observed 
of organizational characteristics taken from each IGO's official documents. These sources included statutes, constitutions, terms of reference or procedural rules for the main bodies, financial regulations, and annual reports. We did our utmost to gather missing data by contacting the IGO secretariat by e-mail. The data that IGO officers provided in this way were included in the database. In an extremely small number of cases, information gaps were filled from data taken from IGOs' websites. Please see Table 1 for description of the data.

Two reasons make this empirical setting suitable to test our hypotheses. First, unlike other organizational types, IGOs exemplify the governance choice on CEO selection by clearly distinguishing whether the principals directly choose the CEO or delegate the CEO selection function to the board. Their official documents explicitly state this governance choice. Second, the unique ownership structure of IGOs demonstrate the two underlying rationales of control and efficiency during CEO selection. Member states as IGO principals are prone to principal-principal agency conflict driving incentives to individual control, while expected to uphold collectivism at the expense of individual control (Nielson \& Tierney, 2003).

\subsection{Measures}

For our dependent variable, we coded a categorical variable indicating whether CEO selection is performed by the principals or the board. We assigned a value of 0 if the principals choose the CEO, whereas a value of 1 if the CEO selection function is delegated to the board. Out of the total number of 69 cases, 34 IGOs have boards delegated with the CEO selection function, while the rest of the 35 IGOs keep the CEO selection function to the principals.

Our explanatory variables consist of two indicators of ownership structures (diversity and dispersion) and three indicators of organizational characteristics (size, complexity, and age). Ownership structure in IGOs can be equated to the membership structure. For ownership diversity, we measured the variable using IGO membership diversity, based on Marshall and Jaggers' (2002) polity index of level of democracy in states to calculate an IGO's internal standard deviation based on its members. The level of democracy provides an indication of state preference and behavior. Similar levels of democracy among states are assumed to have homogenous preference. The greater the IGO's standard deviation regarding the democratic level of its member states, the greater its heterogeneity and thus suggesting diverse preferences within the collective principal. For ownership dispersion, we measured the variable using IGO membership size, taken from IGO annual reports. High number of member states in an IGO would suggest high dispersion. The variable was logged and centered to the mean.

Related to organizational characteristics, organizational size is measured by IGOs' annual expenditures for operations, including projects and administrative expenses, taken from IGOs' annual financial reports. In the case of international financial institutions (IFIs), we excluded capital expenditures, which are not part of the annual budget and are considered as extraordinary events for the IGOs. The variable was also logged and centered to the mean. Meanwhile, we measured 
organizational complexity using Boehmer et al. (2004) IGO codification based on a three-point scale of institutionalization: 1. minimal organizations that involve a small secretariat focusing on research, planning, and information gathering; 2. structured organizations that contain a bureaucracy to implement policy; 3. interventionist organizations that contain mechanisms for mediation, arbitration and adjudication, and/or other means to coerce state decisions. We used minimal IGOs as the reference category for low organizational complexity, and we coded it as 0 . We collapsed categories 2 and 3 to keep degrees of freedom, and because using two different categories for structured and interventionist did not alter the results, and we coded it as 1 as high organizational complexity. Finally, organization age was computed based on IGO founding date. The number of years was also logged and centered on its mean.

We also included two control variables concerning the board and IGO context in our study. First, we controlled for whether board representation is rotational among the member states. The principals would be more willing to relinquish individual control and delegate governance functions to the board if they have the opportunity to serve in the board at some point. Second, we controlled for an industry characteristic of whether the IGO belongs to the financial sector (i.e., IFI) or not. Industry implies the level of technological intensity and environmental dynamism, which determines organizational structures. Compared to other industries, the financial industry entails high informational asymmetry and moral hazard risk, which a board could address. In addition, financial firms are subject to more regulatory requirements than those firms from other industries (Furfine, 2001; Levine, 2004).

We also controlled for two characteristics of the principals: capacity and incentive. On the one hand, previous studies contend that differences in owners' stakes are associated with varying participation in CEO succession processes (e.g., Parrino et al., 2003). We operationalized the capacity of principals as to whether they are unequal peers or not based on their voting rights. On the other hand, prior research argues that principal capacity is not the only factor that influences the likelihood of monitoring; the principals' incentive to monitor can also be an important factor to consider (c.f., Connelly et al., 2010; Dharwadkar et al., 2008). We captured the IGO principals' incentive to monitor using their financial risk, computed through the interaction of the IGO's annual budget and unequal peers.

\subsection{Analytical approach}

Our model assumes that the governance choice underlying CEO selection $\left(y_{i}\right)$ is a Bernoulli distribution of the probability parameter $\operatorname{Bern}\left(p_{i}\right)$. We ran a Bayesian logistic regression analysis on $\left(y_{i}\right)$ against a vector of the explanatory variables $\left(X_{i}\right)$, which also included the hypothesized interaction effects.

$$
\begin{gathered}
y_{i} \sim \operatorname{Bern}\left(p_{i}\right) \\
\operatorname{logit}\left(p_{i}\right)=\theta * X_{i} \\
\theta \sim N(0,10)
\end{gathered}
$$


We used Bayesian procedures for the analytical inference to obtain simulated values of the posterior density of the vector of parameters of interest $(\theta)$, mainly to avoid the assumption that the data are the result of a process of repeated samplingwhich consists of all the global IGOs. Bayesian inference offers advantages to modelling when the ratio of data to estimates is low (as is our case, with 69 cases and willing to estimate 16 parameters). Moreover, we can incorporate a strategy to deal with missing data into the inference process, by assigning prior distributions to the missing values in a conservative way which follows the distribution of observed values. Our estimation model uses the Gibbs sampler (JAGS), based on Markov Chain Monte Carlo, and the "ggmcmc" libraries (Fernández-i-Marín, 2016; Plummer, 2013; Team R, 2013). Our Geweke test has shown no evidence of non-convergence of the series (Geweke, 1992). In addition, Bayesian inference offers higher model flexibility to deal with relatively small sample size (see the introductory chapters of Gelman et al., 2013, Gill, 2002, and Jackman, 2009 for more readings on the advantages of Bayesian inference). It requires specifying prior distributions for the parameters of the model. We have chosen to provide weakly informative priors centered at zero with a standard deviation of 10 , as there is no previous research exploring the governance choice where CEO selection is carried out by the principals or the board.

\subsection{Robustness and predictive power}

The model is robust to the use of wider priors and a more conservative missing data approach. The predictive power of the model can be assessed using a separation plot (Greenhill et al., 2011), as shown in Fig. 1. The separation plot shows how cases are rank-ordered horizontally (the lowest values are on the left) according to their respective probability predicted by the model. In Bayesian logistic regressions, $\mathrm{R}^{2}$ cannot be used to evaluate the model's explanatory power, and the equivalent pseudo $\mathrm{R}^{2}$ has important shortcomings (Greene, 2003).

In Fig. 1, those cases (34) that actually delegate the board the CEO selection function are shaded. A completely accurate model would have all shaded cases on the right and all the other non-shaded cases on the left. The triangle on the horizontal axis marks the division between predicted number of shaded and non-shaded cases according to the model. The threshold in Fig. 1 falls at 27 cases (as opposed to the 34 IGOs that have a board delegated with the CEO selection function). The

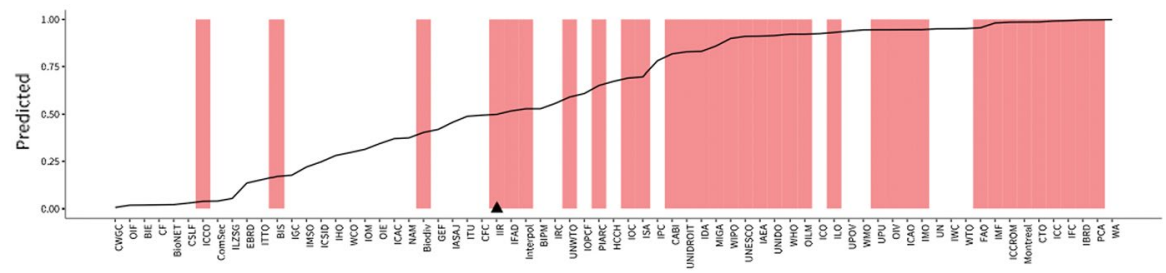

Fig. 1 Separation plot for the nomination of a leading figure of the secretariat model. Percentage correctly predicted $(\mathrm{PCP})=73.9 \%=[21+30] / 69$ 
plot shows on the right-hand side of the triangle 30 IGOs that actually have a board delegated with the CEO selection function and were correctly predicted. Whereas, on the left-hand side of the triangle, the model predicts correctly 21 IGOs where the principals themselves select the CEO. Numerically, the model's percentage of cases correctly predicted (PCP) is $73.9 \%$.

We also performed a robust logistic regression. Our results mirror the reported relationships, thus confirming the robustness of our model (see Appendix for the comparison between the reported and robust check results, plus the more conservative missing data approach).

\section{Results}

The results of the Bayesian logistic regression analysis are extracted from the posterior distributions of the parameters of interest, namely $\theta$. Figure 2 presents their distribution. The dot represents the mean of the posterior distribution and can be understood as the value of the parameter in a frequentist approach. The uncertainty is represented by the thick and thin bands, which cover $95 \%$ and $99 \%$, respectively, of the highest posterior density, the equivalent to the confidence interval in classical statistics (Table 1).

Table 2 presents whether the different hypotheses received support in this study. The variable showing a probability greater than 0.95 suggests evidence that can be equated to significant relationship in classical statistics, although we do not rely on our results to pass the arbitrary threshold of $95 \%$. Results show that ownership structures are not relevantly associated with the governance choice underlying CEO selection, since neither has reached the $95 \%$ threshold and thus

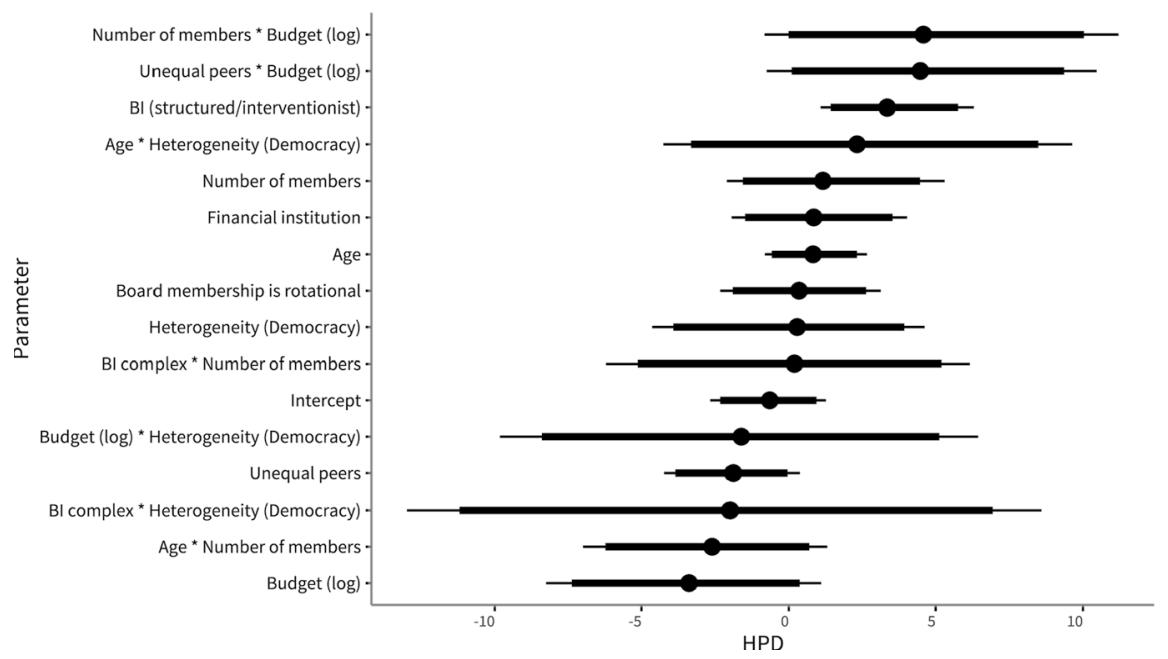

Fig. 2 Caterpillar plot for the effects of the explanatory variables. HPD: Highest probability density. Dots represent the median of the posterior distribution of the parameters, and the thick and thin lines cover the 90 and $95 \%$ credible intervals 
Table 2 Hypotheses and findings

\begin{tabular}{|c|c|c|c|c|c|}
\hline Hypothesis & Support & Coefficient & Prob. $>0$ & Prob. $<0$ & Who selects? \\
\hline \multicolumn{6}{|l|}{ Ownership structure } \\
\hline \multicolumn{6}{|l|}{ Ownership diversity } \\
\hline (H1) Heterogeneity & No & 0.16 & 54.8 & 45.2 & Board \\
\hline \multicolumn{6}{|l|}{ Ownership dispersion } \\
\hline (H2) Number of members & No & 1.29 & 75.8 & 24.2 & Board \\
\hline \multicolumn{6}{|l|}{ Organizational characteristics } \\
\hline \multicolumn{6}{|l|}{ Direct effect } \\
\hline (H3) Organizational complexity: BI complex & Yes & 3.44 & 99.8 & 0.2 & Board \\
\hline (H4) Organizational size: Budget (log) & No & -3.44 & 6.8 & 93.2 & Principals \\
\hline (H5) Organizational age & No & 0.85 & 83.4 & 16.6 & Board \\
\hline \multicolumn{6}{|l|}{ Interactions } \\
\hline (H6a) BI complex * Heterogeneity & No & -2.04 & 35.7 & 64.3 & Principals \\
\hline (H6a) BI complex * Number of members & No & 0.15 & 52.6 & 47.4 & Board \\
\hline (H6b) Budget $(\log ) *$ Heterogeneity & No & -1.62 & 34.3 & 65.7 & Principals \\
\hline (H6b) Budget $(\log ) *$ Number of members & Yes & 4.74 & 95.0 & 5.0 & Board \\
\hline (H6c) Age $*$ Heterogeneity & No & 2.42 & 74.3 & 25.7 & Board \\
\hline$(\mathrm{H} 6 \mathrm{c})$ Age $*$ Number of members & No & -2.64 & 10.3 & 89.7 & Principals \\
\hline \multicolumn{6}{|l|}{ Control variables } \\
\hline Rotational board membership & No & 0.35 & 60.0 & 40.0 & Board \\
\hline Financial institution & No & 0.90 & 71.6 & 28.4 & Board \\
\hline Principal capacity to monitor & Yes & -1.92 & 4.7 & 95.3 & Principals \\
\hline Principal incentive to monitor & Yes & 4.56 & 95.4 & 4.6 & Board \\
\hline
\end{tabular}

$\mathrm{n}=69$; probabilities are in percentage and relevant in values of at least 95

failing to support Hypotheses 1 and 2. However, we find that both ownership structures are associated with the board delegated with the CEO selection function, following the direction of our hypotheses.

With regard to the direct effects of organizational characteristics, we found support for hypothesis 3, suggesting that organizational complexity strongly and clearly increases the likelihood of the CEO selection delegated to the board (with a coefficient of 3.44 and a probability of $99.8 \%$ ). Whereas, there is no evidence supporting hypothesis 4 , in which we found the opposite effect where organizational size increases the likelihood of the principals themselves selecting the CEO (with a coefficient of -3.44 and a probability of $93.2 \%$ ). Meanwhile, there is no evidence to support hypothesis 5 , in which the relationship of organizational age is weak and with modest probability (with a coefficient of 0.85 and a probability of $83.4 \%$ ). Noticeably, we also found that the capacity of owners to monitor is associated with CEO selection performed by the principals themselves (with a coefficient of -1.92 and probability of 95.3), while the incentive of owners to monitor is associated with CEO selection delegated to the board (with a coefficient of 4.56 and probability of 95.4). 
Our hypotheses regarding the moderating effects of different organizational characteristics on CEO selection are barely supported. Only organizational size has a high probability of intensifying the effect of ownership dispersion on CEO selection (with a probability of $95 \%$ ), thereby supporting hypothesis 6b. Organizational age has a modest probability of intensifying the effect of ownership diversity on CEO selection (with a probability of $74.3 \%$ ). Although there is lack of evidence, the rest of the interaction effects are associated with reductions of the effect of ownership structures on CEO selection.

\section{Discussion and conclusion}

The main objective of this research was to identify what influences the governance choice underlying CEO selection, in which the principals would be presented the choice of themselves selecting the CEO or delegating the CEO selection function to the board. In doing so, we generated insights that challenge the current assumptions in the CEO selection literature and strategic governance research in general.

Our findings suggest that ownership structure does not influence this governance choice. On the one hand, although not relevant, ownership diversity is associated with the principals delegating CEO selection to the board. This deviates from prior research suggesting that different ownership types increase fellow owner behavior uncertainty (e.g., Peng et al., 2004), thus making owners pursue individual control to protect self-interests and reduce fellow principal opportunistic behavior (e.g., Chen et al., 2014). Owners seem to follow an efficiency logic, where delegation to the board may overcome the collective principal's gridlock due to internal diversity. On the other hand, although not relevant as well, ownership dispersion is associated with the board delegated with the CEO selection function. This parallels the longstanding economic assumption of agency theory suggesting that the board becomes an efficient governance mechanism in manager-controlled organizations where diffused ownership exists (Jensen \& Meckling, 1976).

Our study also demonstrates the influence of different organizational characteristics on CEO selection. The results show that only organizational complexity and size have high probability of affecting the selection decision, in which size resulted in the opposite hypothesized effect. While the effect of complexity is expected to yield CEO selection to the board, the effect of size leaning toward principal control suggests the tendency of principals to reduce risks corresponding to their amount of investments. Since we used IGO budget as a measure of size, and budget of IGOs largely comes from principal contributions, the likelihood that principals would want to ensure effective control so that their interests are protected becomes a greater concern as well.

As for the probability effect of age, the development of organizational processes over time might not be quite evident in IGOs, as compared to other organizational types. IGOs' legalistic and political nature restricts them from abrupt changes of organizational processes that were agreed among the member states since inception. Decision making in these organizations entails explicit consent from the principals, and thus IGOs typically have strong inertial forces when it comes to changes on 
how the organizations operate (Federo et al., 2020a, 2020b). Trust building may not occur among the principals who are often government representatives with high turnover frequency, as national governments change following domestic electoral cycles. IGOs may not evolve organically, as with the dynamic nature of firms and other nonprofit entities that can easily morph and adjust to environmental needs.

Furthermore, almost none of the organizational variables have relevant moderating effects on the relationship between ownership structure and CEO selection. The only interaction supporting our hypotheses is the moderating effect of organizational size on the effect of ownership dispersion; although organizational age intensifies the effect of ownership diversity, it is not relevant. Our findings mirror previous studies that found no moderating effects of complexity and size on the effect of ownership structures (e.g., Durand \& Vargas, 2003; Greenwood et al., 2007). Interestingly, although with weak evidence, we find that several organizational characteristics have negative moderating effects on the influence of ownership structure on CEO selection. The findings deviate from our expectations that organizational variables should be intensifying such influence. Instead, we found that organizational characteristics likely reduce the effect of ownership structures. This is in line with the barriers view of Boivie and colleagues (2016) regarding organizational characteristics, in which organizational complexity and size exacerbates information processing needs that need to be addressed. We thus provide evidence that organizational level factors are more likely aggravating structural inertia that might influence the governance choice on CEO selection.

It is also worth noting the effect of our control variables. On the one hand, we found that organizations belonging to the financial sector are more likely to delegate the CEO selection to the board. This empirical evidence echoes previous studies suggesting that financial institutions are subject to greater informational asymmetries and moral hazard risk and face greater regulatory requirements by governments than other organizations from other industries (Furfine, 2001; Levine, 2004). Thus, the board becomes the competent body that can perform CEO selection effectively to mitigate adverse selection, while efficiently addressing principal interests. On the other hand, although not relevant, we found that rotational board membership is associated with the board delegated with the CEO selection function. This finding follows the notion that, when the principals are given equal chances to sit on the board, they will be more willing to forego direct control as principals (e.g., Parker, 2007).

We also find that our control variables pertaining to the capacity and incentive of principals are relevant factors influencing CEO selection. This finding suggests that the substantive characteristics of the principals matter more than their structural features; however, they vary on how they influence the governance choice of CEO selection. On the one hand, unequal ownership is associated with CEO selection to be performed by the principals themselves. One explanation for this is the high likelihood that boards are representatives of more powerful states which dissuade other principals to give up control of key organizational decision making when delegating the CEO selection to the board. On the other hand, high owners' incentive is associated with delegating CEO selection to the board. A probable explanation for this is the evident faultline that blurs the distinction between the principals and agents in 
IGOs. Perhaps, because of the significant financial risk involved, powerful principals prefer to delegate the function to the board which likely comprising their representatives, since board decisions in IGOs tend to benefit those member states who are represented in the organizations' boards (c.f., Kaja \& Werker, 2010). In sum, these findings demonstrate the strong political force within IGOs' principal-board relations, since member states as principals have varying levels of power among themselves, influencing how they are likely giving up control over their respective organizations.

\subsection{Implications}

Our study offers two overall implications for our understanding of CEO selection. First, our study contributes to the literature on CEO selection, particularly focusing on the board's important responsibility to appoint the CEO. Rather than tapping into the debate whether boards should choose candidates for the post based on certain individual characteristics, we offer an alternative insight regarding a governance choice where the principals would choose the CEO instead of being delegated to the board. With this path, CEO selection transcends beyond the conventional principal-agent assumption in which boards are delegated with the function to mitigate adverse selection. Instead, our study shows that CEO selection can also be a challenge to address principal interests. This study ultimately opens inquiry to explore the principal-principal conflict (Young et al., 2008) that potentially arises in CEO selection, which will have strong implications for organizational types that are prone to face challenges in mitigating the competing self-interests among the principals. Delegating governance functions to the board might not be the most suitable choice (e.g., Khurana, 2001), particularly when relational uncertainty among principals is high (e.g., Das \& Teng, 1996).

Second, our study highlights the tension between control and efficiency in CEO selection. Previous studies examining these two constructs have largely focused on board-CEO relations (e.g., Gulati \& Westphal, 1999; Sundaramurthy \& Lewis, 2003; Westphal, 1999). We argue that this tension can also be observed in the governance choice of CEO selection. Subsequently, we offer empirical evidence showing the factors (i.e., ownership structure and organizational characteristics) that influence the governance choice. In particular, our findings show that ownership structure by itself is not relevantly associated with CEO selection in IGOs; instead, some organizational characteristics are related to this governance function. One probable explanation for this is the likelihood that member states are not really diverse after all and that the number of members as principals is limited (i.e., there are only about 190 countries).

Nevertheless, although failing to reach relevance levels, diverse and disperse ownerships are more likely to delegate CEO selection to the board. This finding in our context raises a theoretical issue on whether these characteristics of IGO ownership structure that can be observed in organizations with highly homogeneous principals who are capped in number (e.g., joint ventures, partnerships, governmentcontrolled corporations, and firms with high concentration of family stake) are less 
likely to influence CEO selection. It may also be possible that despite the homogeneity of characteristics between the principals, their interests are likely to be heterogeneous (Federo et al., 2020a, 2020b). Ultimately, our study shows that it is the principals' substantive characteristics (i.e., capacity and incentive) that matter more than their structural features (i.e., diversity and dispersion).

In addition, our study has an important implication for policymaking related to CEO selection. In our empirical subjects, CEO selection is explicit in their founding documents that are often strictly followed to mitigate the clash among the principals. However, in contexts in which the principals are highly incentivized to monitor their respective organizations and the faultline between the principals and the board might be blurred (i.e., family and founder-controlled firms, and joint ventures, among others), perhaps it is advisable to include a clause in organizational documents to explicitly identify who should be in-charge in CEO selection, particularly focusing on the substantive characteristics of the principals. We suppose that in doing so can help mitigate the prospective principal-principal conflict that can occur during the CEO selection process.

\subsection{Limitations and future research}

There are also several limitations of our study, thus setting grounds for future research. First, our main focus is identifying the antecedents of CEO selection. In particular, we have only accounted for ownership structures and organizational characteristics as antecedents. However, there may be other behavioral and political factors affecting governance choice, which we have not captured in our study. For example, the power of the principals, personal relationships, and informal networks among the principals could have intervening influence on the relationship between ownership structures and CEO selection. Institutional frameworks (i.e., national rules and regulations) might also have an effect. These factors are highly relevant when it comes to nonprofit and public sector organizations, given that they are more sensitive to the perceptions of their constituency or end-customers who hold them accountable for their public actions (c.f., Koliba et al., 2011; McGravey, 2001; SazCarranza et al., 2020). Nevertheless, these factors can be explored in future studies to substantiate our findings.

Second, our model tackles one leg of the CEO selection process. Future research should also explore how the governance choice underlying CEO selection is associated with organizational outcomes. For instance, examining which governance choice would actually reduce agency costs offers some important implications for both CEO selection research and practice. Also, it would be interesting to know whether principal-appointed CEOs outperform board-appointed CEOs, or vice versa. Moreover, there is a wide spectrum of organizational outcomes that can be explored, such as profitability, strategic orientation, innovation, reputation, and market responses, among others.

Third, there may also be a possibility that our explanatory variables in this study are interrelated or not independent of each other. Scholars urge for a configurational approach in organizational studies (Fiss et al., 2013; Misangyi et al., 2017; 
Parente \& Federo, 2019), which can refine the relationships that we have found in this study - and perhaps also include more explanatory variables. This is crucial when understanding our empirical subjects, since IGOs are argued to have organizational designs embodying multiple interrelated factors and operate within a complex system with multiple layers and multi-faceted conditions (e.g., Chaudoin et al., 2015; Federo, 2019). In addition, given that we cannot establish causality because of our methodology and the relatively small number of cases, a configurational analysis may provide the causal link between the probabilities that we deduce from our findings.

Lastly, our study is conducted on a specific type of organization: global IGOs. Although our sample size risks low power because it is relatively small for a quantitative design-even accounting for the Bayesian statistics that we have used, our findings have high internal validity, given that our analysis is performed in the whole population of the empirical setting and not merely a sample. However, we encourage to explore whether our findings would be context-specific to the organizations studied here by looking also to regional IGOs and other organizational types that have the probability of having a similar governance choice underlying CEO selection. In those organizations, the influence of the owners when it comes to CEO selection is blurred along board decisions. Perhaps, more qualitative inquiry could distinguish the governance choice dilemma in such circumstances.

In conclusion, despite that CEO selection has attracted attention in the literature, several facets of the CEO selection phenomenon remain understudied. In particular, research has overlooked the likelihood that CEOs can be chosen by the principals, and not by the board. We show in this study that CEO selection may also be a governance choice in which the principals are faced with the clashing rationales of control and efficiency. This governance choice is influenced by the owners' substantive characteristics (i.e., capacity and incentive), instead of their ownership structures (i.e., diversity and dispersion), and certain organizational characteristics barely have direct and moderating effects on the relationship between ownership structures and such governance choice. These findings ultimately nuance our understanding of CEO selection as a strategic corporate governance function in organizations.

\section{Appendix}

See Fig. 3. 


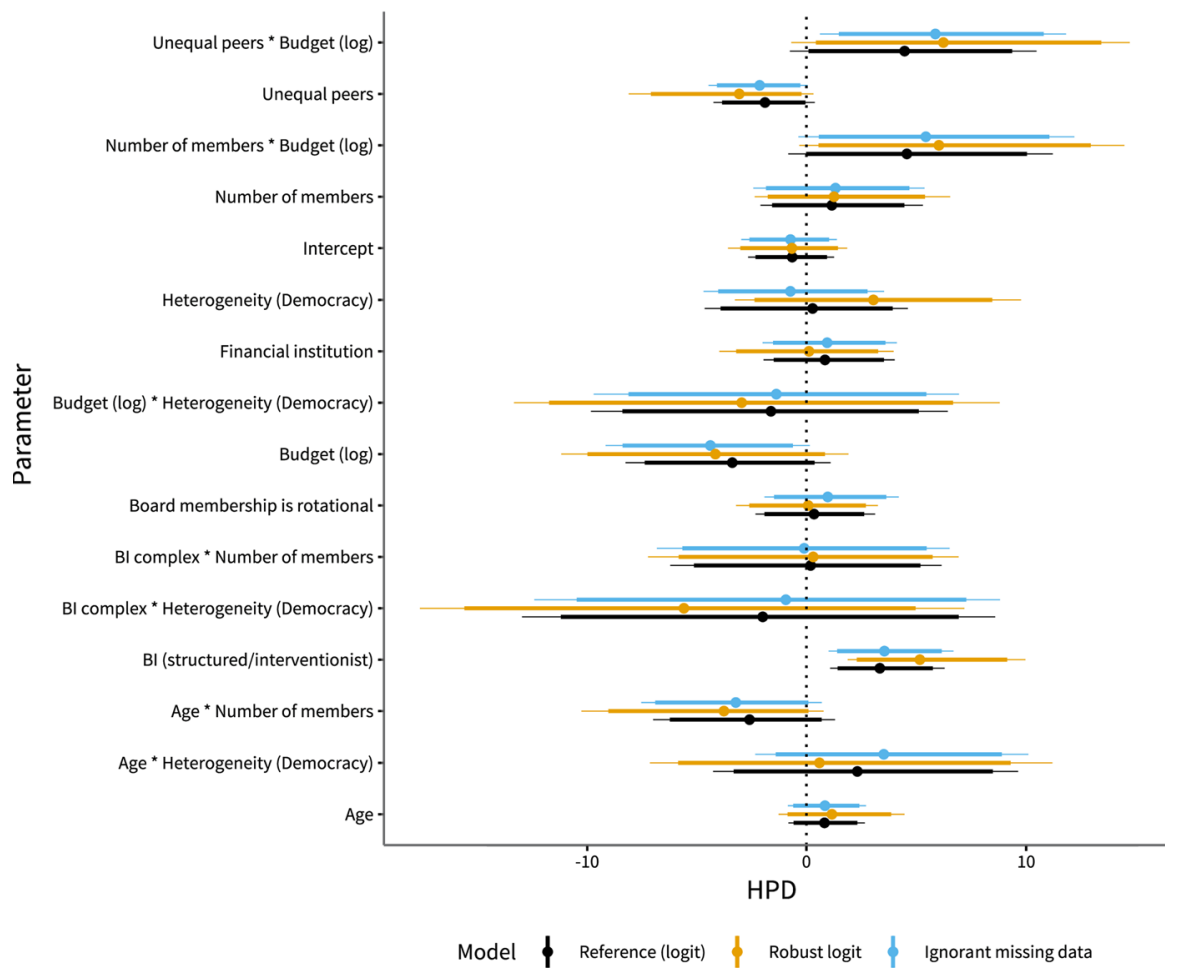

Fig. 3 Comparison between the main results reported in the article and two alternative specifications, for robustness checks. One is with a robust logit regression and another is with a missing data strategy that treats missing data with extreme ignorance

Acknowledgements We would like to thank Lino Cinquini for the editorial guidance and the two anonymous reviewers for their insightful comments and suggestions. Earlier versions of this paper were presented at the 2018 AOM Annual Meeting at Chicago, 2016 Political Economy of International Organizations Annual Conference at University of Utah, 2015 Business and Public Policy Workshop at ESMT Berlin, Germany, and 2015 Barcelona Workshop on Global Governance at ESADE Business School and Institut Barcelona d'Estudis Internacionals, Barcelona, Spain.

Funding Open Access funding provided thanks to the CRUE-CSIC agreement with Springer Nature.

Open Access This article is licensed under a Creative Commons Attribution 4.0 International License, which permits use, sharing, adaptation, distribution and reproduction in any medium or format, as long as you give appropriate credit to the original author(s) and the source, provide a link to the Creative Commons licence, and indicate if changes were made. The images or other third party material in this article are included in the article's Creative Commons licence, unless indicated otherwise in a credit line to the material. If material is not included in the article's Creative Commons licence and your intended use is not permitted by statutory regulation or exceeds the permitted use, you will need to obtain permission directly from the copyright holder. To view a copy of this licence, visit http://creativecommons.org/licen ses/by/4.0/. 


\section{References}

Allcock, D., \& Filatotchev, I. (2010). Executive incentive schemes in initial public offerings: The effects of multiple-agency conflicts and corporate governance. Journal of Management, 36(3), 663-686.

Aguilera, R. V., Filatotchev, I., Gospel, H., \& Jackson, G. (2008). An organizational approach to comparative corporate governance: Costs, contingencies, and complementarities. Organization Science, 19(3), 475-492.

Anderson, R. C., \& Reeb, D. M. (2004). Board composition: Balancing family influence in S\&P 500 firms. Administrative Science Quarterly, 49(2), 209-237.

Bebchuk, L. A., \& Roe, M. J. (1999). A theory of path dependence in corporate ownership and governance. Stanford Law Review, 52, 127.

Berns, K. V., \& Klarner, P. (2017). A review of the CEO succession literature and a future research program. Academy of Management Perspectives, 31(2), 83-108.

Bethel, J. E., \& Liebeskind, J. (1993). The effects of ownership structure on corporate restructuring. Strategic Management Journal, 14(S1), 15-31.

Boehmer, C., Gartzke, E., \& Nordstrom, T. (2004). Do intergovernmental organizations promote peace? World Politics, 57(1), 1-38.

Boeker, W., \& Goodstein, J. (1993). Performance and successor choice: The moderating effects of governance and ownership. Academy of Management Journal, 36(1), 172-186.

Boivie, S., Bednar, M. K., Aguilera, R. V., \& Andrus, J. L. (2016). Are boards designed to fail? The implausibility of effective board monitoring. Academy of Management Annals, 10(1), 319-407.

Brickley, J. A., Smith, C. W., Jr., \& Zimmerman, J. L. (1997). Management fads and organizational architecture. Journal of Applied Corporate Finance, 10(2), 24-39.

Bruderl, J., \& Schussler, R. (1990). Organizational mortality: The liabilities of newness and adolescence. Administrative Science Quarterly, 35, 530-547.

Brunninge, O., \& Nordqvist, M. (2004). Ownership structure, board composition and entrepreneurship: Evidence from family firms and venture-capital-backed firms. International Journal of Entrepreneurial Behavior and Research, 10(1/2), 85-105.

Busenbark, J. R., Krause, R., Boivie, S., \& Graffin, S. D. (2016). Toward a configurational perspective on the CEO: A review and synthesis of the management literature. Journal of Management, 42(1), 234-268.

Bushman, R., Chen, Q., Engel, E., \& Smith, A. (2004). Financial accounting information, organizational complexity and corporate governance systems. Journal of Accounting and Economics, 37(2), $167-201$.

Cannella, A. A., Jr., Jones, C. D., \& Withers, M. C. (2015). Family-versus lone-founder-controlled public corporations: Social identity theory and boards of directors. Academy of Management Journal, 58(2), 436-459.

Cannella, A. A., Jr., \& Lubatkin, M. (1993). Succession as a sociopolitical process: Internal impediments to outsider selection. Academy of Management Journal, 36(4), 763-793.

Chandler, A. D. (1962). Strategy and structure: History of the industrial enterprise. MIT.

Charan, R. (2016). The secrets of great CEO selection. Harvard Business Review, 94(12), 52-59.

Chaudoin, S., Milner, H. V., \& Pang, X. (2015). International systems and domestic politics: Linking complex interactions with empirical models in international relations. International Organization, 69(2), 275-309.

Chen, G., \& Hambrick, D. C. (2012). CEO replacement in turnaround situations: Executive (mis) fit and its performance implications. Organization Science, 23(1), 225-243.

Chen, V. Z., Li, J., Shapiro, D. M., \& Zhang, X. (2014). Ownership structure and innovation: An emerging market perspective. Asia Pacific Journal of Management, 31(1), 1-24.

Child, J., \& Rodrigues, S. B. (2003). Corporate governance and new organizational forms: Issues of double and multiple agency. Journal of Management and Governance, 7(4), 337-360.

Chung, K. H., Rogers, R. C., Lubatkin, M., \& Owers, J. E. (1987). Do insiders make better CEOs than outsiders? Academy of Management Perspectives, 1(4), 325-331.

Coffee, J. C., Jr. (2001). The rise of dispersed ownership: The roles of law and the state in the separation of ownership and control. Yale LJ, 111, 1.

Connelly, B. L., Tihanyi, L., Certo, S. T., \& Hitt, M. A. (2010). Marching to the beat of different drummers: The influence of institutional owners on competitive actions. Academy of Management Journal, 53(4), 723-742. 
Corbetta, G., \& Salvato, C. (2004). Self-Serving Or self-actualizing? Models of man and agency costs in different types of family firms: a commentary on "Comparing the agency costs of family and nonfamily firms: Conceptual issues and exploratory evidence. Entrepreneurship Theory and Practice, 28(4), 355-362.

Cyert, R. M., \& March, J. G. (1963). A behavioral theory of the firm. Englewood Cliffs NJ, 2(4), 169-187.

Daily, C. M., Dalton, D. R., \& Rajagopalan, N. (2003). Governance through ownership: Centuries of practice, decades of research. Academy of Management Journal, 46(2), 151-158.

Dalton, D. R., \& Kesner, I. F. (1983). Inside/outside succession and organizational size: The pragmatics of executive replacement. Academy of Management Journal, 26(4), 736-742.

Das, T. K., \& Teng, B. S. (1996). Risk types and inter-firm alliance structures. Journal of Management Studies, 33(6), 827-843.

Datta, D. K., \& Guthrie, J. P. (1994). Executive succession: Organizational antecedents of CEO characteristics. Strategic Management Journal, 15(7), 569-577.

Datta, D. K., \& Rajagopalan, N. (1998). Industry structure and CEO characteristics: An empirical study of succession events. Strategic Management Journal, 19(9), 833-852.

Demsetz, H., \& Lehn, K. (1985). The structure of corporate ownership: Causes and consequences. Journal of Political Economy, 93(6), 1155-1177.

Denis, D. K., \& McConnell, J. J. (2003). International corporate governance. Journal of Financial and Quantitative Analysis, 38(1), 1-36.

Dharwadkar, R., Goranova, M., Brandes, P., \& Khan, R. (2008). Institutional ownership and monitoring effectiveness: It's not just how much but what else you own. Organization Science, 19(3), 419-440.

Dooley, K. (2002). Organizational complexity. International Encyclopedia of Business and Management, $6,5013-5022$.

Durand, R., \& Vargas, V. (2003). Ownership, organization, and private firms' efficient use of resources. Strategic Management Journal, 24(7), 667-675.

Federo, R. (2019). Qualitative comparative analysis. In Introduction to International Organization Research Methods, Forthcoming.

Federo, R., Ponomareva, Y., Aguilera, R. V., Saz-Carranza, A., \& Losada, C. (2020a). Bringing owners back on board: A review of the role of ownership type in board governance. Corporate Governance: An International Review, 28(6), 348-371.

Federo, R., \& Saz-Carranza, A. (2018). A configurational analysis of board involvement in intergovernmental organizations. Corporate Governance: An International Review, 26(6), 414-428.

Federo, R., \& Saz-Carranza, A. (2020). A typology of board design for highly effective monitoring in intergovernmental organizations under the United Nations system. Regulation \& Governance, 14(2), 344-361.

Federo, R., Saz-Carranza, A., \& Esteve, M. (2020b). Management and governance of intergovernmental organizations. Cambridge University Press.

Fernández-i-Marín, X. (2016). ggmcmc: Analysis of MCMC samples and Bayesian inference. Journal of Statistical Software, 70(9), 1-20.

Filatotchev, I., \& Bishop, K. (2002). Board composition, share ownership, and 'underpricing' of UK IPO firms. Strategic Management Journal, 23(10), 941-955.

Finkelstein, S., \& Hambrick, D. C. (1989). Chief executive compensation: A study of the intersection of markets and political processes. Strategic Management Journal, 10(2), 121-134.

Fiss, P. C., Cambré, B., \& Marx, A. (Eds.). (2013). Configurational theory and methods in organizational research. Emerald Group Publishing.

Furfine, C. H. (2001). Banks as monitors of other banks: Evidence from the overnight federal funds market. The Journal of Business, 74(1), 33-57.

Gelman, A., Stern, H. S., Carlin, J. B., Dunson, D. B., Vehtari, A., and Rubin, D. B. (2013). Bayesian data analysis. Chapman and Hall/CRC.

Geweke, J. (1992). Evaluating the accuracy of sampling-based approaches to the calculations of posterior moments. Bayesian statistics, 4, 641-649.

Giambatista, R. C., Rowe, W. G., \& Riaz, S. (2005). Nothing succeeds like succession: A critical review of leader succession literature since 1994. The Leadership Quarterly, 16(6), 963-991.

Gill, J. (2002). Bayesian methods: A social and behavioral sciences approach. Chapman and Hall/CRC.

Goel, A. M., \& Thakor, A. V. (2008). Overconfidence, CEO selection, and corporate governance. The Journal of Finance, 63(6), 2737-2784.

Gorton, G., \& Schmid, F. (1999). Corporate governance, ownership dispersion and efficiency: Empirical evidence from Austrian cooperative banking. Journal of Corporate Finance, 5(2), 119-140. 
Greckhamer, T. (2016). CEO compensation in relation to worker compensation across countries: The configurational impact of country-level institutions. Strategic Management Journal, 37(4), 793-815.

Greene, W. H. (2003). Econometric analysis. Pearson Education India.

Greenhill, B., Ward, M. D., \& Sacks, A. (2011). The separation plot: A new visual method for evaluating the fit of binary models. American Journal of Political Science, 55(4), 991-1002.

Greenwood, R., Deephouse, D. L., \& Li, S. X. (2007). Ownership and performance of professional service firms. Organization Studies, 28(2), 219-238.

Greenwood, R., \& Empson, L. (2003). The professional partnership: Relic or exemplary form of governance? Organization Studies, 24(6), 909-933.

Groot, T. L., \& Merchant, K. A. (2000). Control of international joint ventures. Accounting, Organizations and Society, 25(6), 579-607.

Gulati, R., Puranam, P., \& Tushman, M. (2012). Meta-organization design: Rethinking design in interorganizational and community contexts. Strategic Management Journal, 33(6), 571-586.

Gulati, R., \& Westphal, J. D. (1999). Cooperative or controlling? The effects of CEO-board relations and the content of interlocks on the formation of joint ventures. Administrative Science Quarterly, 44(3), 473-506.

Guthrie, J. P., \& Datta, D. K. (1998). Corporate strategy, executive selection, and firm performance. Human Resources Management, 37(2), 101-115.

Haas, E. B. (1990). When knowledge is power: Three models of change in international organizations (Vol. 22). University of California Press.

Hall, R. H., Johnson, N. J., \& Haas, J. E. (1967). Organizational size, complexity, and formalization. American Sociological Review, 32, 903-912.

Hambrick, D. C., \& Mason, P. A. (1984). Upper echelons: The organization as a reflection of its top managers. Academy of Management Review, 9(2), 193-206.

Hammer, T. H., \& Stern, R. N. (1980). Employee ownership: Implications for the organizational distribution of power. Academy of Management Journal, 23(1), 78-100.

Hannan, M. T., \& Freeman, J. (1984). Structural inertia and organizational change. American Sociological Review, 49(2), 149-164.

Handler, W. C. (1994). Succession in family business: A review of the research. Family Business Review, 7(2), 133-157.

Hawkins, D. G., Lake, D. A., Nielson, D. L., \& Tierney, M. J. (Eds.). (2006). Delegation and agency in international organizations. Cambridge University Press.

Henderson, A. D., \& Fredrickson, J. W. (1996). Information-processing demands as a determinant of CEO compensation. Academy of Management Journal, 39(3), 575-606.

Hermalin, B. E., and Weisbach, M. S. (2001). Boards of directors as an endogenously determined institution: A survey of the economic literature (No. w8161). National Bureau of Economic Research.

Herman, R. D., Renz, D. O., \& Heimovics, R. D. (1996). Board practices and board effectiveness in local nonprofit organizations. Nonprofit Management and Leadership, 7(4), 373-385.

Herrmann, P., \& Datta, D. K. (2002). CEO successor characteristics and the choice of foreign market entry mode: An empirical study. Journal of International Business Studies, 33(3), 551-569.

Hoskisson, R. E., Hitt, M. A., Johnson, R. A., \& Grossman, W. (2002). Conflicting voices: The effects of institutional ownership heterogeneity and internal governance on corporate innovation strategies. Academy of Management Journal, 45(4), 697-716.

Jackman, S. (2009). Bayesian analysis for the social sciences (Vol. 846). Wiley.

Jensen, M. C., \& Meckling, W. H. (1976). Theory of the firm: Managerial behavior, agency costs and ownership structure. Journal of Financial Economics, 3(4), 305-360.

Johnson, T., \& Urpelainen, J. (2014). International bureaucrats and the formation of intergovernmental organizations: Institutional design discretion sweetens the pot. International Organization, 68(1), 177-209.

Kaja, A., \& Werker, E. (2010). Corporate governance at the World Bank and the dilemma of global governance. The World Bank Economic Review, 24(2), 171-198.

Kale, P., Dyer, J. H., \& Singh, H. (2002). Alliance capability, stock market response, and long-term alliance success: The role of the alliance function. Strategic Management Journal, 23(8), 747-767.

Kang, J. K., \& Shivdasani, A. (1995). Firm performance, corporate governance, and top executive turnover in Japan. Journal of Financial Economics, 38(1), 29-58.

Kesner, I. F., \& Sebora, T. C. (1994). Executive succession: Past, present and future. Journal of Management, 20(2), 327-372. 
Khurana, R. (2001). Finding the right CEO: Why boards often make poor choices. MIT Sloan Management Review, 43(1), 91-95.

Koliba, C. J., Mills, R. M., \& Zia, A. (2011). Accountability in governance networks: An assessment of public, private, and nonprofit emergency management practices following Hurricane Katrina. Public Administration Review, 71(2), 210-220.

La Porta, R., Lopez-de-Silanes, F., \& Shleifer, A. (1999). Corporate ownership around the world. The Journal of Finance, 54(2), 471-517.

Le Mens, G., Hannan, M. T., \& Pólos, L. (2015). Age-related structural inertia: A distance-based approach. Organization Science, 26(3), 756-773.

Leech, D., \& Leahy, J. (1991). Ownership structure, control type classifications and the performance of large British companies. The Economic Journal, 101(409), 1418-1437.

Levine, R. (2004). The corporate governance of banks: A concise discussion of concepts and evidence. The World Bank.

Marshall, M. G., Jaggers, K., \& Gurr, T. R. (2002). Polity IV project: Political regime characteristics and transitions, 1800-2002. University of Maryland.

Mayer, R. C., Davis, J. H., \& Schoorman, F. D. (1995). An integrative model of organizational trust. Academy of Management Review, 20(3), 709-734.

McGarvey, N. (2001). Accountability in public administration: A multi-perspective framework of analysis. Public Policy and Administration, 16(2), 17-29.

Miller, D., Kets de Vries, M. F., \& Toulouse, J. M. (1982). Top executive locus of control and its relationship to strategy-making, structure, and environment. Academy of Management Journal, 25(2), 237-253.

Misangyi, V. F., Greckhamer, T., Furnari, S., Fiss, P. C., Crilly, D., \& Aguilera, R. (2017). Embracing causal complexity: The emergence of a neo-configurational perspective. Journal of Management, 43(1), 255-282.

Mitchell, W. (1994). The dynamics of evolving markets: The effects of business sales and age on dissolutions and divestitures. Administrative Science Quarterly, 39, 575-602.

Mizruchi, M. S. (1983). Who controls whom? An examination of the relation between management and boards of directors in large American corporations. Academy of Management Review, 8(3), 426-435.

Mohr, J., \& Spekman, R. (1994). Characteristics of partnership success: Partnership attributes, communication behavior, and conflict resolution techniques. Strategic Management Journal, 15(2), $135-152$.

Mooney, C. H., Semadeni, M., \& Kesner, I. F. (2017). The selection of an interim CEO: Boundary conditions and the pursuit of temporary leadership. Journal of Management, 43(2), 455-475.

Nielson, D. L., \& Tierney, M. J. (2003). Delegation to international organizations: Agency theory and World Bank environmental reform. International Organization, 57(2), 241-276.

Ocasio, W., \& Kim, H. (1999). The circulation of corporate control: Selection of functional backgrounds of new CEOs in large US manufacturing firms, 1981-1992. Administrative Science Quarterly, 44(3), 532-562.

Olson, M. (1965). The logic of collective action: Public goods and the theory of groups. Harvard University Press.

Parente, T., \& Federo, R. (2019). Qualitative comparative analysis: Justifying a neo-configurational approach in management research. RAUSP Management Journal, 54(4), 399-412.

Parker, L. D. (2007). Internal governance in the nonprofit boardroom: A participant observer study. Corporate Governance: An International Review, 15(5), 923-934.

Parrino, R., Sias, R. W., \& Starks, L. T. (2003). Voting with their feet: Institutional ownership changes around forced CEO turnover. Journal of Financial Economics, 68(1), 3-46.

Peng, M. W., Tan, J., \& Tong, T. W. (2004). Ownership types and strategic groups in an emerging economy. Journal of Management Studies, 41(7), 1105-1129.

Phan, P. H., Siegel, D. S., \& Wright, M. (2005). Science parks and incubators: Observations, synthesis and future research. Journal of Business Venturing, 20(2), 165-182.

Pierce, J. L., \& Delbecq, A. L. (1977). Organization structure, individual attitudes and innovation. Academy of Management Review, 2(1), 27-37.

Plummer, M. (2013). rjags: Bayesian graphical models using MCMC. R package version, 3(10).

Pugh, D. S., Hickson, D. J., Hinings, C. R., \& Turner, C. (1968). Dimensions of organization structure. Administrative Science Quarterly, 13, 65-105. 
Reuer, J. J., Klijn, E., van den Bosch, F. A., \& Volberda, H. W. (2011). Bringing corporate governance to international joint ventures. Global Strategy Journal, 1(1-2), 54-66.

Saz-Carranza, A., Albareda, A., \& Federo, R. (2020). Network tasks and accountability: A configurational analysis of EU regulatory networks. Public Administration, 98(2), 480-497.

Sebora, T. C., \& Kesner, I. F. (1996). The CEO selection decision process: Bounded rationality and decision component ordering. Journal of Multi-Criteria Decision Analysis, 5(3), 183-194.

Smith, B. F., \& Amoako-Adu, B. (1999). Management succession and financial performance of family controlled firms. Journal of Corporate Finance, 5(4), 341-368.

Stuart, T. E., \& Podolny, J. M. (1996). Local search and the evolution of technological capabilities. Strategic Management Journal, 17(S1), 21-38.

Sundaramurthy, C., \& Lewis, M. (2003). Control and collaboration: Paradoxes of governance. Academy of Management Review, 28(3), 397-415.

Sur, S., Lvina, E., \& Magnan, M. (2013). Why do boards differ? Because owners do: Assessing ownership impact on board composition. Corporate Governance: An International Review, 21(4), 373-389.

Team R C (2013). R: A language and environment for statistical computing.

Westphal, J. D. (1999). Collaboration in the boardroom: Behavioral and performance consequences of CEO-board social ties. Academy of Management Journal, 42(1), 7-24.

Westphal, J. D., \& Fredrickson, J. W. (2001). Who directs strategic change? Director experience, the selection of new CEOs, and change in corporate strategy. Strategic Management Journal, 22(12), 1113-1137.

Young, M. N., Peng, M. W., Ahlstrom, D., Bruton, G. D., \& Jiang, Y. (2008). Corporate governance in emerging economies: A review of the principal-principal perspective. Journal of Management Studies, 45(1), 196-220.

Zahra, S. A., \& Pearce, J. A. (1989). Boards of directors and corporate financial performance: A review and integrative model. Journal of Management, 15(2), 291-334.

Zajac, E. J. (1990). CEO selection, succession, compensation and firm performance: A theoretical integration and empirical analysis. Strategic Management Journal, 11(3), 217-230.

Zajac, E. J., \& Westphal, J. D. (1996). Who shall succeed? How CEO/board preferences and power affect the choice of new CEOs. Academy of Management Journal, 39(1), 64-90.

Zhang, Y., \& Rajagopalan, N. (2003). Explaining new CEO origin: Firm versus industry antecedents. Academy of Management Journal, 46(3), 327-338.

Zhang, Y., \& Rajagopalan, N. (2010). Once an outsider, always an outsider? CEO origin, strategic change, and firm performance. Strategic Management Journal, 31(3), 334-346.

Zucker, L. G. (1986). Production of trust: Institutional sources of economic structure, 1840-1920. Research in Organizational Behavior, 8, 53-111.

Publisher's Note Springer Nature remains neutral with regard to jurisdictional claims in published maps and institutional affiliations. 